\title{
A study of factors affecting inheritance success in family businesses in Kerala
}

\section{Bhasi and V.V. Renuka*}

School of Management Studies,

Cochin University of Science \& Technology,

Kochi, India

Email: drbhasi@gmail.com

Email: renuvvenu@gmail.com

*Corresponding author

\section{S. Rajkumar}

\author{
Sree Kailas BusinesGroup, \\ Kochi, India \\ Email: rajkumar@sreekailas.com
}

\begin{abstract}
Family business contributes significantly to the Indian economy, their existence and survival is therefore important. Generational transition is the time when many family businesses or business families fail. In this empirical study the effect of selected owner and business related factors on success of inheritance in family businesses in Kerala is examined. Based on the responses from one hundred and fifty current owners of family businesses in Kerala, we have identified the important owner and business related factors that have significant impact on the chance of success of inheritance in the family business. Two owner-related factors, religion and age, and two business related factors, size of business and nature of constitution of organisation were found to have significant impact on the chance of success of inheritance management in family business.
\end{abstract}

Keywords: inheritance; family business; religion; size; India.

Reference to this paper should be made as follows: Bhasi, M., Renuka, V.V. and Rajkumar, S. (2020) 'A study of factors affecting inheritance success in family businesses in Kerala', Int. J. Family Business and Regional Development, Vol. 1, No. 1, pp.62-80.

Biographical notes: M. Bhasi received his Bachelor of Technology degree in Production in 1986; and Master of Technology in Industrial Engineering in1988 and $\mathrm{PhD}$ in Industrial Management in 1997 from the Indian Institute Technology, Kharagpur. He was employed in ICIM as Marketing Executive for over a year and then taught at Cochin University for the last 23 years. He has also served as the Managing Director of CONSUMERFED, Kerala for nearly three years. He is currently the Director of the School of Management Studies of Cochin University. He is a member of IEEE and a life member of the IIIE and Kerala Management Association. He has 14 international and 47 national journal publications. His research interests are in the areas of operations management, information systems and project management. He has guided 12 $\mathrm{PhD}$ thesis. 
V.V. Renuka is an MBA holder with specialisations in Finance and HRM. She is currently a part time research scholar in Cochin University of Science \& Technology. She is working as an Assistant Professor in the Faculty of commerce in M.P.M.M.S.N.Trusts College, Shoranur, Kerala. She is pursuing Research in Management of Inheritance in Family business. Her areas of interest include human resource and entrepreneurial development.

S. Rajkumar is a first generation entrepreneur and CEO of the Sree Kailas Business Group. He has business interest in Kraft papers, boards, transportation, real estate, housing and logistics. Their business establishments are located in states of Kerala and Tamilnadu. He has a Post Graduate in Commerce from University of Kerala. This paper is a part of his Doctoral work in the area of management of inheritance in family business in Kerala.

\section{Introduction}

Managing a family business provides a great opportunity to grow together and build a lasting legacy, but at the same time it is a very challenging one (Ramachandran, 2015). According to Chua (1999) "The family business is a business governed and/or managed with the intention to shape and/or pursue the vision of the business held by a dominant coalition controlled by members of the same family or a small number of families in a manner that is potentially sustainable across generations of the family or families". Family owned firms are organisations where two or more extended family members influence the directions of the business through the exercise of kinship ties, management roles or ownership rights (Davis and Tagiuri, 1982). The statistics show that succession is typically a challenging issue. The survival rate of family business shows a downward trend, i.e. only $30 \%$ of the family business survive the transition to second generation and only $10 \%$ make it to the third generation and the average life span of the firm is about 24 years, which is also the average life tenure of the founder of the firm (Beckard and Dyer, 1983). In family business we can say that ownership and management transition and preparation of heirs are the important challenges faced by the family business.

Some merits of family businesses are its long term perspective; greater independence of action with less pressure from the stock market, less takeover risk, less bureaucracy, continuity in leadership, greater resilience in hard times with a willingness to plow back profits is some of the other often observed positive features (Vries, 1993). Long term orientation is positively associated with innovativeness, proactiveness, and autonomy but negatively associated with risk taking and competitive aggressiveness (Lumpkin et al., 2010).

The family culture being a source of pride, there is stability, strong identification, commitment and motivation. Family business owners pride themselves in being able to provide family members with career opportunities in the business. The family business provides a great training ground for family members who aspire to pursue business careers elsewhere or within the family business. Family businesses are not without their own set of problems. There is always a possibility that first generation become incompetent to bring about changes so as to adapt with the new situations. In addition to this, the passage of a family business from one generation to the next leads to lot of difficulties. A study done among East African entrepreneurs shows that they use strong 
community ties to counterbalance the obligations that strong extended family ties create (Khavul et al., 2009).

These challenges can be reduced to an extent by a thorough understanding of the family business dynamics. Each generation has a different culture and family members should understand this fact. Families have to learn about the cultural differences between generations and try to understand their perspectives. Thus, if family businesses can manage these dynamics, they will be better placed to reap the benefits of the great range of opportunities in the Indian economy and beyond.

\subsection{Succession planning}

It is estimated that assets of over US\$15 trillion will pass from one generation to the next, as baby boomers who own family business reaches retirement age (Zaudtke and Ammerman, 1997). Succession planning in a family business is a deliberate and a formal process that facilitates the transfer of management control of family members, thereby helping the transition process (Sharma et al., 2003a). The main reason for high failure of the family business is the lack of succession planning (Handler, 1990). This lack of succession planning according to Seymour (1993) is due to certain factors like founder's strong sense of attachment to the business, fear of retirement and death. Ibrahim and Ellis (2004) and Gallo (1995) noted that succession is a complex process which involves many factors, evolving over a long period of time. One problem facing the successors is that, usually the owners have implicit rather than explicit understanding of family successor requirements, they often leave potential successors in the dark regarding their expectations; thus, descendants may need to guess which attributes they should contribute to the firm (Boyd et al., 2015).

India has a culture that is unique and very different from that of the west, therefore separate studies are required for understanding problems related to inheritance management in the Indian context. This study has been conducted with the objectives stated below to bridge this gap. This study was designed to cover the state of Kerala in India.

\subsection{Geographical region}

Kerala, regionally referred to as Keralam, is a state in the south-west region of India. It was formed on 1 November 1956 as per the States Reorganization Act by combining various Malayalam-speaking regions. Spread over 38,863 square kilometres, Kerala is the state with the lowest positive population growth rate in India (3.44\%) and has a density of 860 people per square kilometres. The culture of the state traces its roots from $3 \mathrm{rd}$ century CE. It is a blend of Aryan and Dravidian cultures, developed over centuries under influences from other parts of India and abroad.

\section{Research problem}

This work is an endeavour to explain the success of inheritance in family business in Kerala, one of the south-western corner of India, a state actively associated with small entrepreneurial belt of businesses. The question at the forefront is: What are the 
owner-related and business-related factors which influence the chance of success of inheritance in family business in Kerala?

\section{Research design}

An operational definition for family business was first given after review of literature. From literature and discussion with experts associated with management of inheritance in family businesses, including successful 2nd generation entrepreneurs, possible factors related to current owner and the family business were listed for further use. Items for the questionnaire were developed to measure chance of success of inheritance management in the family business and all factors identified. The sampling and data collection are discussed later. In the sections that follow the operational definition for family business and a discussion on the owner and business related factors that were included in the study is presented.

\subsection{Family business}

Family business is one in the ownership and or functioning of which, two or more members of the same family are directly involved and the ownership of which, passes from one generation of the family to another.

\section{Factors identified for testing}

Although family business has been in existence for thousand years, it was only in the past forty years that researchers have become interested in the family business as a separate discipline and a topic of scholarly inquiry. Some of the topics of interest to researchers are the characteristics of the founder-entrepreneur, the role of family in the business, the involvement of children in business, overpowering father, underachieving as well as overachieving son, the role of daughter, conflicts of members in family, social and ownership structure of family business, culture and vision of the founder, governance, succession planning, reluctance to let go, leadership transfer and non family executive. Churchill and Hatten (1987) proposed that family business goes through four transitional stages which are: owner and manager, training and development of the new generation, partnership between the generation and actual transfer of power. A major research area in the field during the past 20 years has been and still is the issue of succession in the family business. Succession or passing the baton to next generation is one of the main characteristics that distinguish a family business from a non family business and can be viewed as a process that involves many factors and evolved over a period of time. Most of the literature reviews on succession revolve around multi-level model of succession process that includes factors at the micro (individual attributes), meso (interpersonal or group relations) and macro (firms processes and strategies) levels of analysis.

\subsection{Dependent variable-chance of success of inheritance management}

Goldberg (1996), Harvey and Evans (1995) and Hume (1999) point out that not only the satisfaction of various stakeholders in the succession process defines a successful 
succession, but also the successor's ability to keep the family business healthy by means of sustained growth and profitability. We have chosen chance of success as dependent variable in place of effective or successful succession for two reasons. The first reason is that literature has shown chance of success as a significant predictor of effective or successful succession and second, it helps to include family businesses who are preparing for succession in the study.

The success of inheritance management in family business is dependent on many attributes of current owner such as effective leadership, founders' reluctance to let go and management style adopted. There is a strong individual autonomy orientation at the owners level and it significantly influences the personal attitude and this in turn will affect the management of family business (Moog et al., 2011). The success of inheritance management depends on many attributes of business such as extent of succession planning, estate planning, strategic planning etc. In a study among Scottish family businesses, it is found that timing, cultural knowledge and conflict resolution are seen as keys to successful succession (Seaman et al., 2013). Numerous studies have been undertaken with the above factors especially in American and Europeans settings.

After discussion with experts and selected multi-generation family business owners, we selected current owners religion, age, education and districts as variables to that could impact chance of success of inheritance of family business and business size, type of organisation, generation which started family business and extent of professionalisation of business to measure the impact of business related factors on chance of success of inheritance management in family business. These factors are briefly discussed next.

\subsection{Owner's religion}

Religion and its impact on enterprising culture was first analysed by Weber (1930) in the western context. All through the history of Kerala, religion has been a significant part of state's culture. Religion in Kerala is a blend of different faiths, most significantly Hinduism, Islam and Christianity. One of the greatest competitive advantage of family firm is that strong values and cultures that family can bring to the firms. And many families see their religion as the basis of their values. The innovative business values coupled with traditional family values serves as a competitive advantage for the business continuity (Erdem and Base, 2010).

Hinduism in Kerala is a combination of Dravidian and Aryan cultures and religious practices. Hinduism provides little encouragement or value to change one's situation in terms of material well being (Singer, 1966). Dharma (righteousness), artha (earnings), kama (desire), moksha (liberation) are supposed to guide the lives of Hindus. Hindu cultures are basically opposed to acquisition of wealth, and a businessman is looked upon as a profiteer, hoarder and black marketer and therefore held in low esteem. But this traditional view is slowly changing.

Muslims are commonly referred to as Mappilas in Kerala. They share Malayalam culture of Kerala with an Arabian blend. Even during the pre-Islamic period Kerala has a very ancient relation with middle east. Muslim merchants settled in Kerala by the 8th century $\mathrm{AD}$ and introduced Islam. Major populations of Muslims live in Calicut, Malappuram districts in Malabar region.

According to Indian census, Christianity is the third most practiced religion in Kerala with around $20 \%$ of population according to Indian census. The origin of Kerala 
Christians dates back to AD 52, when St. Thomas, one of the disciples of Jesus Christ is believed to have landed at Kodungalloor in Trissur district, in the central part of Kerala.

The inheritance law is different for followers of different religion in Kerala. Under Hindu succession act, prior to statutory amendment of 2005 , only sons could acquire a share in the joint family property by birth. So on the partition of the joint family the persons entitled to a share in the property were the father, mother and son. The daughter could only inherit her father's $1 / 3$ rd share in the joint family property after his death. The 2005 amendment redressed this anomaly by making the daughter a coparcener in the joint family property. Christians and Parsis are governed by the Indian Succession Act and do observe the principle of gender equality in succession. Daughters and sons are treated equally. As the inheritance is different, religion will have an impact on succession decisions. In order to gain a deeper understanding of success of inheritance in family business, we must consider the religious environment in which they operate.

Owners' religion in this study has been classified into three groups: Hindu, Muslim and Christian.

\subsection{Owner's age}

As Lansberg (1988) notes, the family's approach to succession planning is often highly related to the founder's age. Research shows that older executives tend to have a stronger commitment to the organisation (Becker, 1973) and to be more risk averse (Carlsson and Karlsson, 1970). As the owner ages, their awareness of the need to prepare for the inevitable transition of ownership and control increases, and along with it, the need for succession planning. Advancing age, the inevitability of death, and the threat of debilitating illness tends to compel the owner to make preparation for the continuity of the family business. Davis' (1982) survey of one hundred fifty-four men stated that harmonious relationship exists between father and son when the father was age 50-59 and the son was age 23-32. The relationship between father and son is seen to become problematic when the father was the age 60-69 and son was age 34-40. Only weak support was obtained for the hypothesis that a problematic relationship between father and son would exist when the father was 41-45 and the son was17-22. The relationship that exists between father and son plays a vital role in the successful inheritance. Owner's age has therefore been taken as one of the factors under study. Owner's age has been classified into four groups: below 40 years, above $40-50$ years, above 50-60 years and above 60 years.

\subsection{Owner's education}

There are some studies of family businesses which show a positive relationship between education and innovation (Kimberly and Evanisko, 1981), while others (Datta and Guthrie, 1994) have associated the owner's level of formal education with the willingness to implement change. While these studies provide no clear confirmation of a positive relation between owner education and succession planning, nevertheless, they do provide a basis, however tentative, for conjecturing that there is one. An excellent level of education and professional skills, combined with good on-the-job training with the senior are further determinants for the successful continuation of a family business (Schroer and Freund, 1999). Owner's education has therefore been taken as one of the factors under 
study. Owners' education has been classified into three groups: owner's education up to 10 th, 10 th to degree, masters and above masters.

\subsection{Owner's district/region}

Kerala was ruled by three administrations-two princely states, Travancore and Cochin, and Malabar which was under the direct administration of British at the time of independence. The historical background of the Kerala reveal that the Malabar region on one-hand and Travancore and Cochin regions on other, had different socio-historical backgrounds leading to their present social, educational and economic status. Travancore became the second most prosperous princely state in British India, with reputed achievements in education, political administration, public work and social reforms. So we selected the owner's district as one of factors that impacts chance of success of inheritance management. Owners' district/region has been classified into three groups: central region, northern region and southern region.

\subsection{Size of organisation}

Trow (1961) argued that large companies tend to have more elaborated training programs and complex succession plans than do small firms. Thus, we would expect a positive relation between the size of the organisation and its preparations for the succession. Furthermore, larger organisations have the resources to engage the outside counsel that might encourage planning for succession. They also have access to external consultants whose professional advice may facilitate the succession planning process (Chaganti et al., 1985). These factors alone might ensure that larger family businesses would have more qualified, experienced candidates in place for possible succession. Stavrou (1999) pointed out that business size and the intention of the successor to join the family business are positively correlated. Size of organisation has therefore been taken as one of the factors under study. Size of organisation has been classified into three groups: up to 100 crore, 101 to 500 crore, 501 to 1,000 crore.

\subsection{Nature of constitution of organisation}

As per the data collected, the nature of constitution of organisation is classified into: proprietorship, partnership, public limited and private limited.

From the study it is found that $26.5 \%$ are having proprietary business, $28.5 \%$ with partnership business. The percentage of respondents with private limited company is $33.8 \%$ and $11 \%$ public limited companies.

\subsection{Generation of the family business}

Mannheim (1952) described generations as social factorions whereby those of a particular age or set of ages are defined by historical and social events. There is a Chinese saying that claimed "wealth does not may be endured three generations". This statement may be a concurrence or not, but many family business suffer from this phenomenon (Ngui, 2002). Generation of family business has therefore been taken as one of the factors under study. 
Dyer (1989) found that $80 \%$ of 1 GFFs had a 'paternalistic' management culture and style, but that in succeeding generations more than two-thirds of these firms adapted a 'professional' style of management. 'Paternalistic' management was characterised by hierarchical relationships, top management control of power and authority, close supervision, and distrust of outsiders. 'Professional' management involved the inclusion, and sometimes the predominance, of non-family managers in the firm. Generation of family business has been classified into three groups: parents started, grandparents started, great grandparents or above started.

\subsection{Extent of professionalisation of business}

Professionals play an important role in family business (Ibrahim et al., 2001). The professionals may have particular knowledge of the firm that may be proved to be valuable in mentoring of the future-generation leaders or filling in the leadership role (Lee et al., 2003). In larger firms, professionals have been found to play a critical role in the strategic decision making in family business (Chua et al., 2003). The main reason for professionalisation is the lack of management talent within the family business and second reason for professionalising the management is to change the norms and values of business operations (Dyer, 1989). Extent of professionalisation of business has therefore been taken as one of the factors under study. In a study conducted among private Belgian family businesses, five underlying dimensions for professionalisation was developed. They are financial control systems, non family involvement in governance systems' human resource control systems, decentralisation of authority and top level activeness (Dekker et al., 2015)

Extent of professionalisation of business has been classified into three groups: high level, medium level and low level.

\section{Data collection}

The research design that is adopted is a combination of exploratory and explanatory designs. A schedule was used to collect data for this study. The geographical area covered was the state of Kerala in India. The population being finite but unknown, nonprobabilistic sampling method was used.

It was decided to go in for a judgmental cum snowball sampling method. The first few respondents for the sample were selected on the basis of convenience. Snow balling was used to gain contacts and introductions to other Family Business owners known to the respondent. Judgment was used to select from between the contacts obtained keeping the sampling objectives of covering different levels of the factors under investigation, which are religion, size of business, district and education of the owner. It was decided to start with a quota of at least 25 respondents from each level of these factors. The adequacy of samples collected as checked after data collection and was found adequate. 


\section{Reliability and validity}

Owner related factors such as owner's religion, age. district/region, education and organisation related factors such as size of organisation, nature of constitution of organisation, generation of family running the business are based on the factual responses and therefore are reliable by themselves. The dependent variable chance of success of inheritance management and one business related factor extent of professionalisation of family business are based on multiple responses for which reliability needs to be checked. Items used to measure the factor 'extent of professionalisation of family business' are extent of involvement in management', 'level of dependence for HRD on managers', 'level of dependence for finance on mangers', 'level of dependence for marketing on managers', 'level of dependence for production managers' and 'managers level of decision making power'. Computed Cronbach's alpha is equal to .814 which is much above the acceptable value of 0.7 suggested by Hair et al. (2012) and hence the measure is found reliable.

Items used to measure the dependent variable chance of success of inheritance management are "I am very concerned with passing the business to next generation", "I know how to pass the business to next generation" , "I am doing enough to make passing the business to next generation successful", "my family is very cooperative with me on issues relating to passing the business to next generation", "the inheritors chosen are willing to take over the business", "the business is also made ready for take over". Reliability is this case is also adequate, since Cronbach's alpha is equal to .931 which is much above the acceptable value of 0.7 suggested by Hair et al. (2012).

The validity of the construct 'chance of success of inheritance management' shows an average loading factor of .854 and 'extent of professionalisation of family business' shows an average loading factor of .882 which is much acceptable value of 0.7 and both of them shows a valid measure and they are tested against opinion of experts from the Chamber of Trade and Commerce and also other experts in the field of family business.

\section{Analysis and discussion}

Data analysis was done using SPSS. The dependent factor used in the study is the chance of success of inheritance management in family business. In order to check whether the selected variables have an impact on chance of success, null hypothesis that each of the variables taken one at a time has no impact on the chance of success were stated and tested. For testing the hypothesis, cross tabulation between the selected factor and chance of success was done and chi-square test was carried out. Consistent with the preceding logic and empirical evidence, we tested the following hypothesis: 
H01 The religion of the owner of family business has no effect on the chance of success of inheritance management.

Table 1 Cross tabulation between religion of owner and chance of success in FB inheritance

\begin{tabular}{lcccccc}
\hline Religion & \multicolumn{5}{c}{ Chance of success in FB inheritance } & \multirow{2}{*}{ Total } \\
\cline { 2 - 6 } & Very low & Low & Medium & High & Very high & \\
\hline Hindu & 10 & 15 & 13 & 28 & 5 & 71 \\
Christian & 2 & 4 & 4 & 11 & 20 & 41 \\
Muslim & 4 & 8 & 8 & 13 & 5 & 38 \\
Total & 16 & 27 & 25 & 52 & 30 & 150 \\
\hline
\end{tabular}

Table 1.1 Chi-square test between religion of owner and chance of success in FB inheritance

\begin{tabular}{lccc}
\hline & Value & $d f$ & Asymp. sig. (two-sided) \\
\hline Pearson chi-square & 30.207 & 8 & .000 \\
Likelihood ratio & 28.448 & 8 & .000 \\
Linear-by-linear association & 15.059 & 1 & .000 \\
N of valid cases & 150 & & \\
\hline
\end{tabular}

The results in Table 1.1 show that null hypothesis framed and tested as H0 1 above is rejected and the alternate hypothesis that 'the religion of the owner of the family business has an effect on chance of success of inheritance management on it', is accepted. A correlation analysis between the religion of the owner of the family business and chance of success shows a moderate (Pearson's correlation coefficient of 0.317) positive correlation between the variables. The literature on family business has not fully investigated the impact of religion on the chance of success of inheritance management in family business. It is found in the literature that Hindu culture is basically opposed to entrepreneurship. While Muslim and Christian populations are more likely to start their own small enterprises, many scholars assert that entrepreneurial activity is central to economic growth in the modern economy. Therefore, the importance of understanding the relationship between religion and an individual's economic decision-making process helps societies unveil potential opportunities for growth and development. Our research results also agree with literature. The Christian family businesses are having the highest chance of success of inheritance followed by Muslims. Hindus have the lowest chance of success of inheritance management. The Christian family businesses have higher chance of success may be because they have higher transformative potential that tend to facilitate entrepreneurial behaviour (Audretsch, 2009). Both Christians and Muslims have regular religious practices revolving arround churches and mosques. These communities have stronger brotherhood ties and get help from religious leaders in solving family related problems. They also have a strong religious study mechanism which instills a common value system in the young ones. These could be the reasons for the better performance of Christians and Muslims in management of inheritance in family businesses. 
H02 The age class of owner of family business has no effect on the chance of success of inheritance management.

Table 2 Cross tabulation between age of owner and chance of success in FB inheritance

\begin{tabular}{lcccccc}
\hline \multirow{2}{*}{ Age class of owner } & \multicolumn{5}{c}{ Chance of success in FB inheritance } & \multirow{2}{*}{ Total } \\
\cline { 2 - 6 } & Very low & Low & Medium & High & Very high & \\
\hline Below 40 years & 10 & 7 & 8 & 12 & 4 & 41 \\
Above 40 to 50 years & 2 & 4 & 9 & 9 & 7 & 31 \\
Above 50 to 60 years & 4 & 15 & 7 & 23 & 9 & 58 \\
Above 60 years & 0 & 1 & 1 & 8 & 10 & 20 \\
Total & 16 & 27 & 25 & 52 & 30 & 150 \\
\hline
\end{tabular}

Table 2.1 Chi-square test between age of owner and chance of success in FB inheritance

\begin{tabular}{lccc}
\hline & Value & $d f$ & Asymp. sig. (two-sided) \\
\hline Pearson chi-square & 33.315 & 12 & .001 \\
Likelihood ratio & 32.811 & 12 & .001 \\
Linear-by-linear association & 13.752 & 1 & .000 \\
N of valid cases & 150 & & \\
\hline
\end{tabular}

The results in Table 2.1 show that null hypothesis framed and tested as H02 above is rejected and the alternate hypothesis that 'the age class of the owner of the family business has an effect on chance of success of inheritance management on it', is accepted. A correlation analysis between age class of owner of the family business and chance of success shows a moderate (Pearson's correlation coefficient of 0.303 ) positive correlation between the variables. Both anecdotal evidence and empirical results suggest this. Malone (1989) found no empirical support for a hypothesised relationship between the extent of succession planning and age of the owner. Sharma (1997) pointed out that owner's intention to step down plays an important role in the extent of succession planning rather than the age of the owner. In our study, it is found that the age of the owner has a significant impact on the chance of success of inheritance and this could be because in certain life stages, it is easier for the owners to share knowledge and interested in the development of a successor.

HO3 The level of education of the owner of the family business has no effect chance of success of inheritance management.

Table 3 Cross tabulation between education of owner and chance of success in FB inheritance

\begin{tabular}{lcccccc}
\hline \multirow{2}{*}{ Education of owner } & \multicolumn{5}{c}{ Chance of success in FB inheritance } & \multirow{2}{*}{ Total } \\
\cline { 2 - 6 } & Very low & Low & Medium & High & Very high & \\
\hline Up to 10th & 5 & 5 & 6 & 10 & 6 & 32 \\
SSLC to degree & 9 & 15 & 14 & 28 & 16 & 82 \\
Masters and above masters & 2 & 7 & 5 & 14 & 8 & 36 \\
Total & 16 & 27 & 25 & 52 & 30 & 150 \\
\hline
\end{tabular}


Table 3.1 Chi-square test between education of owner and chance of success in FB inheritance

\begin{tabular}{lccc}
\hline & Value & $d f$ & Asymp. sig. (two-sided) \\
\hline Pearson chi-square & 2.444 & 8 & .964 \\
Likelihood ratio & 2.534 & 8 & .960 \\
Linear-by-linear association & 1.009 & 1 & .315 \\
N of valid cases & 150 & & \\
\hline
\end{tabular}

The results in Table 3.1 show that null hypothesis framed and tested as H03 above is accepted and that 'the level of education of the owner of the family business has no effect on chance of success of inheritance management on it' is accepted. Even though there are mixed results on the impact of education of owners on family business and the chance of success on inheritance in literatures. This study shows that there is no relationship between the formal education of the owner and chance of success. The management knowledge and experience the current owner has gained in various life cycles of the family business plays an important role.

H04 The district from which the owner of the family business belongs has no effect on chance of success of inheritance management.

Table 4 Cross tabulation between district in Kerala and chance of success in FB inheritance

\begin{tabular}{lcccccc}
\hline \multirow{2}{*}{$\begin{array}{l}\text { Districts in } \\
\text { Kerala }\end{array}$} & \multicolumn{5}{c}{ Chance of success in FB inheritance } & \multirow{2}{*}{ Total } \\
\cline { 2 - 6 } & Very low & Low & Medium & High & Very high & \\
\hline Central region & 2 & 12 & 11 & 27 & 16 & 68 \\
Northern region & 8 & 6 & 7 & 7 & 3 & 31 \\
Southern region & 6 & 9 & 7 & 18 & 11 & 51 \\
Total & 16 & 27 & 25 & 52 & 30 & 150 \\
\hline
\end{tabular}

Table 4.1 Chi-square tests between district in Kerala and chance of success in FB inheritance

\begin{tabular}{lccc}
\hline & Value & $d f$ & Asymp. sig. (two-sided) \\
\hline Pearson chi-square & 11.052 & 8 & .199 \\
Likelihood ratio & 10.543 & 8 & .229 \\
Linear-by-linear association & 5.615 & 1 & .018 \\
N of valid cases & 150 & & \\
\hline
\end{tabular}

The results in Table 4.1 show that null hypothesis framed and tested as H04 above is rejected and the alternate hypothesis that 'the district to which the owner of the family business belongs has no effect on chance of success of inheritance management in it', is accepted. As Kerala is a small state which has a linguistic based culture the distinction is more due to religion than due to the district in which the owner belongs. 
H05 The size of the family business organisation has no effect on the chance of success of inheritance management.

Table 5 Cross tabulation between size of organisation and chance of success in family business inheritance

\begin{tabular}{lcccccc}
\hline \multirow{2}{*}{ Size of organisation } & \multicolumn{5}{c}{ Chance of success in FB inheritance } & \multirow{2}{*}{ Total } \\
\cline { 2 - 6 } & Very low & Low & Medium & High & Very high & \\
\hline Up to 100 & 16 & 24 & 23 & 36 & 16 & 115 \\
101 to 500 & 0 & 1 & 0 & 5 & 11 & 17 \\
501 to 1,000 & 0 & 2 & 2 & 11 & 3 & 18 \\
Total & 16 & 27 & 25 & 52 & 30 & 150 \\
\hline
\end{tabular}

Table 5.1 Chi-square tests between size of organisation and chance of success in family business inheritance

\begin{tabular}{lccc}
\hline & Value & $d f$ & Asymp. sig. (two-sided) \\
\hline Pearson chi-square & 34.472 & 8 & .000 \\
Likelihood ratio & 34.610 & 8 & .000 \\
Linear-by-linear association & 11.951 & 1 & .001 \\
N of valid cases & 150 & & \\
\hline
\end{tabular}

The results in Table 5.1 show that null hypothesis framed and tested as (H05) is rejected and alternate hypothesis is accepted. A correlation analysis between size of organisation and chance of success shows a small but positive correlation (.282) between variables. Both anecdotal evidence and empirical results suggest that there is a positive relationship between business size and the intentions of inheritors to join the family business at some point in their careers (Stavrou, 1999). The successor's willingness to take over the family business is an important aspect for a successful transition. Those participants who owned large business are more tending to join the family business. These may be related to monetary and non monetary rewards available in large businesses. Our study also supports the literature in which we found that size of family business has a significant impact on the chance of success of inheritance of family business (E.Venter et al., 2005)

H06 The nature of constitution of the family business organisation has no effect on the chance of success of inheritance management.

Table 6 Cross tabulation between nature of constitution of organisation and chance of success in FB inheritance

\begin{tabular}{llcccccc}
\hline \multirow{2}{*}{ Type of organisation } & \multicolumn{5}{c}{ Chance of success in FB inheritance } & \multirow{2}{*}{ Total } \\
\cline { 2 - 6 } & Pery low & Low & Medium & High & Very high & \\
\hline \multirow{3}{*}{$\begin{array}{l}\text { Type of } \\
\text { organisation }\end{array}$} & Partnership & 4 & 9 & 8 & 8 & 4 & 39 \\
& Pvt Ltd & 2 & 9 & 10 & 18 & 5 & 43 \\
\multirow{5}{*}{ Total } & Public Ltd & 0 & 3 & 0 & 4 & 9 & 52 \\
\hline
\end{tabular}


Table 6.1 Chi-square tests between and nature of constitution of organisation chance of success in FB inheritance

\begin{tabular}{lccc}
\hline & Value & $d f$ & Asymp. sig. (two-sided) \\
\hline Pearson chi-square & 35.061 & 12 & .000 \\
Likelihood ratio & 35.173 & 12 & .000 \\
Linear-by-linear association & 19.372 & 1 & .000 \\
N of valid cases & 150 & & \\
\hline
\end{tabular}

The results in Table 6.1 show that null hypothesis framed and tested as (H06) is rejected and alternate hypothesis is accepted. he correlation analysis shows a moderate but positive correlation (.359) between variables. The nature of the constitution of the family business organisation changes the chance of success also increases.

HO7 The generation which started the family business has no effect on the chance of success of inheritance management.

Table 7 Cross tabulation between generation of family business and chance of success in FB inheritance

\begin{tabular}{|c|c|c|c|c|c|c|c|}
\hline \multirow{2}{*}{\multicolumn{2}{|c|}{ Generation of family business }} & \multicolumn{5}{|c|}{ Chance of success in FB inheritance } & \multirow{3}{*}{$\begin{array}{r}\text { Total } \\
38\end{array}$} \\
\hline & & \multirow{2}{*}{$\begin{array}{c}\text { Very } \\
\text { low }\end{array}$} & \multirow{2}{*}{$\frac{\text { Low }}{4}$} & \multirow{2}{*}{$\frac{\text { Medium }}{3}$} & \multirow{2}{*}{$\begin{array}{c}\text { High } \\
14\end{array}$} & \multirow{2}{*}{$\begin{array}{c}\begin{array}{c}\text { Very } \\
\text { high }\end{array} \\
15\end{array}$} & \\
\hline Generation of & Parents started & & & & & & \\
\hline ramily ousiness & $\begin{array}{l}\text { Grandparents } \\
\text { started }\end{array}$ & 11 & 16 & 18 & 19 & 10 & 74 \\
\hline & $\begin{array}{l}\text { Great GP or } \\
\text { above started }\end{array}$ & 3 & 7 & 4 & 19 & 5 & 38 \\
\hline Total & & 16 & 27 & 25 & 52 & 30 & 150 \\
\hline
\end{tabular}

Table 7.1 Chi-square tests between generation of family business and chance of success in FB inheritance

\begin{tabular}{lccc}
\hline & Value & Df & Asymp. sig. (two-sided) \\
\hline Pearson chi-square & 23.484 & 8 & .003 \\
Likelihood ratio & 22.754 & 8 & .004 \\
Linear-by-linear association & 3.393 & 1 & .065 \\
N of valid cases & 150 & & \\
\hline
\end{tabular}

The results in Table 7.1 show that the null hypothesis framed and tested as H07above is rejected and the alternate hypothesis that 'the generation which started the family business has an effect on chance of success of inheritance management in it' is accepted. A correlation analysis between generation which started the family business and chance of success shows a small negative (Pearson's correlation coefficient of -0.150 ) correlation between the variables. The time circumstances and duration of transfer also have an influence on the success of generational change (Alcorn, 1982). Our study also agree with the literature in which we found that as the business goes from second generation to the third generation and from fourth generation to fifth generation the chance of success of inheritance in family business shows a downward trend (Beckhard 
and Dyer, 1983). It may be because of the lack of preparation of a good succession plan or an abrupt and unplanned generational change.

H08 Extent of professionalisation of business has no effect on the chance of success of inheritance management.

Table 8 Cross tabulation between extent of professionalisation of business and chance of success of FB inheritance

\begin{tabular}{lcccccc}
\hline \multirow{2}{*}{$\begin{array}{l}\text { Extent of } \\
\text { professionalisation }\end{array}$} & \multicolumn{5}{c}{ Chance of success in FB Inheritance } & \multirow{2}{*}{ Total } \\
\cline { 2 - 6 } & Very low & Low & Medium & High & Very high & \\
\hline High level & 0 & 0 & 0 & 0 & 1 & 1 \\
Low level & 1 & 2 & 0 & 10 & 6 & 19 \\
Medium level & 13 & 19 & 18 & 26 & 10 & 86 \\
Total & 2 & 6 & 7 & 16 & 13 & 44 \\
\hline
\end{tabular}

Table 8.1 Chi-square tests between extent of professionalisation of business and chance of success of FB inheritance

\begin{tabular}{lccc}
\hline & Value & $d f$ & Asymp. sig. (two-sided) \\
\hline Pearson chi-square & 22.223 & 12 & .035 \\
Likelihood ratio & 24.859 & 12 & .016 \\
N of valid cases & 150 & & \\
\hline
\end{tabular}

The results in Table 8.1 shows that null hypothesis framed and tested as H08 above is accepted and that 'the extent of professionalisation of business has no effect on the chance of success of inheritance management' is accepted. The distinctive aspect of professionalisation in the context of private family business is the family involvement in the top level of family business and a choice between a family manager and an external non family - often referred to as professional-manager. However, this causes most empirical studies on professionalisation within the family business context to only focus on this particular feature and neglecting other aspects (Bennedsen et al., 2007; Dyer, 1989).In our study, we found there is no relationship between the extent of professionalisation and chance of success of inheritance in the family business. Many of the family firms in Kerala are not professionalised mainly because of high operational cost, financial constraints, poor infrastructure and lack of a succession plan.

Table 9 Reliability statistics-chance of success of inheritance management

\begin{tabular}{lc}
\hline \multicolumn{2}{c}{ Reliability statistics } \\
\hline Cronbach's alpha & Nof items \\
\hline .931 & 6 \\
\hline
\end{tabular}


Table 10 Reliability statistics- extent of professionalisation of family business

\begin{tabular}{lc}
\hline \multicolumn{2}{c}{ Reliability statistics } \\
\hline Cronbach's alpha & N of items \\
\hline .814 & 6 \\
\hline Table $11 \quad$ Correlation coefficient - relationship between chance of success of inheritance \\
& management and owner's religion, age, size of business, nature of constitution of \\
& organisation and generation of business \\
\hline Variables & Correlation coefficient \\
\hline Owners religion & .317 \\
Owners age & .303 \\
Size of business & .282 \\
Type of organisation & .359 \\
Generation of family business & -.150 (negative correlation) \\
\hline
\end{tabular}

Table 12 Validity-chance of success of inheritance management

\begin{tabular}{lc}
\hline \multicolumn{2}{c}{ Component matrix } \\
\hline & Component \\
\cline { 2 - 2 } I do enough to pass business to next gen & 1 \\
Inheritors willing to take over business & .933 \\
Family cooperative in passing business to next gen & .924 \\
I know to pass business to next gen & .894 \\
Business ready for take over & .881 \\
Concern in passing business to next gen & .805 \\
\hline
\end{tabular}

Table 13 Validity-extent of professionalisation of family business

\begin{tabular}{lc}
\hline & Component matrix \\
\hline & \\
\cline { 2 - 2 } & Component \\
\hline Level of dependence for HRD & 1 \\
Level of dependence for production & .870 \\
Level of dependence for marketing & .811 \\
Managers level of decision making power & .747 \\
Level of dependence for finance & .741 \\
Extent of involvement in management & .718 \\
\hline
\end{tabular}




\section{Conclusions}

Based on our discussions in the preceding sections, we propose a model for the success of inheritance management in the family businesses in Kerala. The factors that show correlation with chance of success of inheritance are ranked in the model.

Figure 1 Model proposed for success of inheritance management in family business

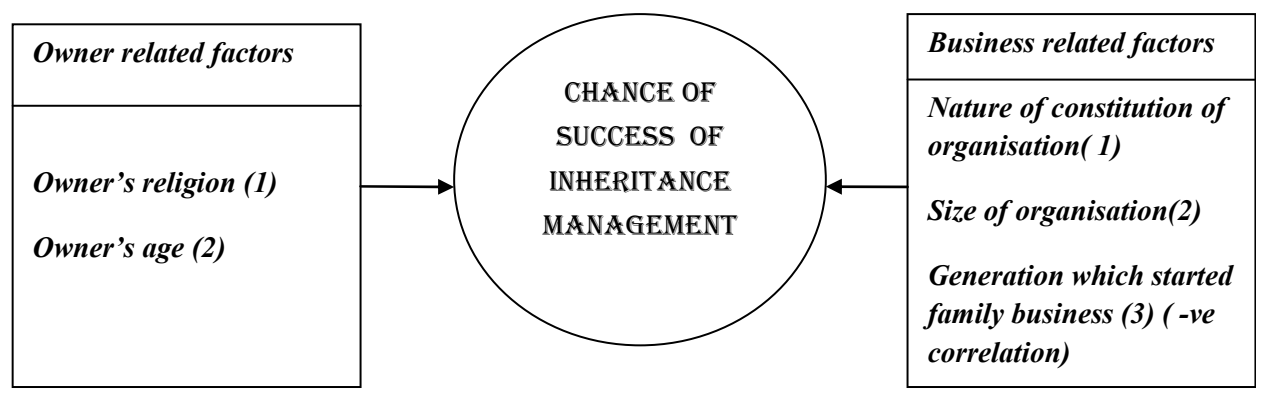

The dependent factor used was the chance of success measured based on a perception of the current owner. This could have induced errors of bias. The study has limitations that are applicable to all surveys based studies. As the study is based on data collected from one hundred and fifty family firms in Kerala, the findings can probably not be generalised to other countries.

From the research it is seen that presently family businesses rely maximum on owner's competence. They may continue to do so. However, in the long run, there is a need to strengthen management in family businesses by inducting outside professionals. This will result in separation of ownership from management, which has proven to be a sure way of ensuring multigenerational survival of family business organisations. The chance of success of inheritance management is higher for first generation and then it starts to slow down. The main reason may be that the inheritors may not have the same passion, competence, commitment as that of the founders. Now that owner-related factors, religion and age, and two business related factors, size of business and type of organisation were found to have significant impact on the chance of success of inheritance management in family business, there is need to understand how these factors play a role in impacting chance of success. The process once understood will help in spreading the best practices identified where ever possible. With better knowledge in this area, family business owners would be in a position to give due importance to managing inheritance and putting enough effort for it. This will ultimately lead to a higher chance of success of inheritance management in Family Businesses in Kerala.

\section{References}

Alcorn, P.B. (1982) Success and Survival in Family-Owned Firm, McGraw Hill, New York.

Audretsch, D.B. (2009) 'Religion, culture and entrepreneurship in India', IPAA 2009 International Public Affairs Conference.

Becker,E.(1973) The Denial of Death, Free Press, New York. 
Beckhard, R. and Dyer, W. (1983a) 'Managing change in the family firm - issues and strategies', Sloan Management Review, Vol. 24, pp.59-65.

Bennedsen, M., Nielsen, K.M., Pérez-González, F. and Wolfenzon, D. (2007) 'Inside the family firm: the role of families in succession decisions and performance', Quarterly Journal of Economics, May, forthcoming.

Boyd, B., Royer, S., Pei, R. and Zhang, X. (Renee) (2015) 'Knowledge transfer in family business successions: implications of knowledge types and transaction atmospheres', Journal of Family Business Management, Vol. 5, No. 1, pp.17-37.

Carlsson, G. and Karlsson, K. (1970) 'Age, cohorts and the generation of generations', American Sociological Review, Vol. 35, pp.710-718.

Chaganti, R.S., Mahajan, V. and Sharma, S. (1985) 'Corporate board size, composition and corporate failures in the retailing industry', Journal of Management Studies, Vol. 22, No. 4, pp.400-417.

Chua, J.H., Chrisman, J.J. and Sharma, P. (1999) 'Defining the family business by behavior', Entrep. Theory Practice, Vol. 23, No. 4, pp.19-37.

Chua, J.H., Chrisman, J.J. and Sharma, P. (2003) 'Succession and non succession concerns of family firms and agency relationship with nonfamily managers', Family Business Review, Vol. 16, pp.89-107.

Churchill, N.C. and Hatten, K.J. (1987) 'Non-market-based transfers of wealth and power: a research framework for family businesses', American Journal of Small Business, Vol. 11, No. 3, pp.51-64.

Datta, D.K. and Guthrie, J.P. (1994) 'Executive succession: organizational antecedents of CEO characteristics', Strategic Management Journal, Vol. 15, pp.569-577.

Davis, J.A. (1982) The Influence of Life-stage on Father-son Work Relationship in Family Companies, Unpublished doctoral dissertation, Harvard Business School.

Davis, J.A. and Tagiuri, R. (1982) Bivalent Attributes of the Family Firm, Owner Managed Business Institute, Santa Barbara, CA.

Dekker, J., Lybaert, N., Steijvers, T. and Depaire, B. (2015) 'The effect of family business professionalization as a multidimensional construct on firm performance', Journal of Small Business Management, Vol. 53, No. 2, pp.516-538, Online publication date: 1 April 2015.

Dyer, W.G. (1989) 'Integrating professional management into a family owned business', Family Business Review, Vol. 2, No. 3, pp.221-235.

E.Venter, C. (2005) 'The influence of successor related factors on the succession process in small and medium-sized family business', Family Business Review, Vol. 18, No. 4, pp.283-303.

Erdem, F. and Base, G.G. (2010) 'Family and business values of regional family firms: a qualitative research', International Journal of Islamic and Middle Eastern Finance and Management, Vol. 3, No. 1, pp.47-64.

Gallo, M. (1995) 'The role of family business and its distinctive characteristic behaviour in industrial activity'. Family Business Review, Vol. 8, pp.83-97.

Goldberg, S. (1996) 'Effective successors in family-owned businesses: significant elements', Family Business Review, Vol. 9, pp.185-197.

Hair, J.F., Sarstedt, M., Ringle, C.M. and Mena, J.A. (2012) 'An assessment of the use of partial least squares structural equation modeling in marketing research', Journal of the Academy of Marketing Science, Vol. 40, No. 3, pp.414-433.

Handler, W.C. (1990) 'Succession in family firms: a mutual role adjustment between entrepreneur and next-generation family members', Entrepreneurship: Theory and Practice, Vol. 15, No. 1, pp.37-51.

Harvey, M. and Evans, R. (1995) 'Strategic windows in the entrepreneurial process', Journal of Business Venturing, Vol. 10, No. 5, pp.331-348.

Hume, S.A. (1999) An Assessment of the Risk of Family Business Failure, Unpublished doctoral dissertation, Antioch University, NH. 
Ibrahim, A.B. and Ellis, W.H. (2004) Family Business Management - Concepts and Practice, 2nd ed., Kendall/Hunt, Dubuque, Iowa, USA.

Ibrahim, A.B., Soufani, K. and Lam, J. (2001) 'A study of succession in a family firm”, Family Business Review, Vol. 14, pp.245-258.

Kimberly, J.R. and Evanisko, M.J. (1981) 'Organizational innovation: the influence of individual, organizational and contextual factors on hospital adoption of technological and administrative innovations', Academy of Management Journal, Vol. 24, pp.689-713.

Lansberg, I. (1988) 'The succession conspiracy', Family Business Review, Vol. 1, pp.119-143.

Lee, D.S., Lim, G.H. and Lim, W.S. (2003) 'Family business succession: appropriation risk and choice of successor', Academy of Management Review, Vol. 28, No. 4, pp.657-666.

Malone (1989) 'Selected correlates of business continuity plans in family business', Family Business Review, Vol. 2, No. 4, pp.341-353.

Mannheim, K. (1952) 'The problem of generations', in Mannheim, K. (Ed.): Essays on the Sociology of Knowledge, first published 1923, RKP, London.

Moog, P., Mirabella, D. and Schlepphorst, S.(2011) 'Owner orientations and strategies and their impact on family business', International Journal of Entrepreneurship and Innovation Management, Vol. 13, No. 1, pp.95-112.

Ngui, C.Y.K. (2002) 'Asian family businesses: from riches to rags?', Malaysian Business, Vol. 2, p.27.

Ramachandran, K. (2015) The 10 Commandments for Family Business, SAGE Publications India Pvt. Ltd., New Delhi, India, Vol. 187,pp.645, ISBN: 978-93-515-0138-1 [HB].

Schröer, E. and Freund, W. (1999) 'Neue Entwicklungen auf dem Markt für die Übertragung mittelständischer Unternehmen', IfM, Bonn.

Seaman, C., Welsh, R. and Bent, R. (2013) 'Succession planning in minority ethnic family enterprises', International Journal of Entrepreneurship and Small Business, Vol. 20, No. 4, pp.402-419.

Seymour, K.C. (1993) 'Intergenerational relationships in the family firm: the effect on leadership succession', Family Business Review, No. 3, pp.263-281.

Sharma, P. (1997) Determinants of the Satisfaction of the Primary Stakeholders with the Succession Process in Family Firms, Unpublished doctoral dissertation, University of Calgary, Canada.

Sharma, P., Chrisman, J.J. and Chua, J.H. (2003a) 'Predictors of satisfaction with the succession process in family firms', Journal of Business Venturing, Vol. 18, No. 5, pp.667-687.

Singer, M. (1966) 'Religion and social change in India: the Max Weber thesis phase three', Economic Development and Cultural Change, Vol. 14, pp.497-505.

Stavrou, E. (1999) 'Succession in family businesses: exploring the effects of demographic factors on offspring intentions to join and take over the business', Journal of Small Business Management, Vol. 37, No. 3, pp.43-62.

Trow, D.B. (1961) 'Executive succession in small companies', Administrative Science Quarterly, Vol. 6, pp.228-239.

Vries, M.F. (1993) 'The dynamics of family controlled firms: the good and the bad news', Organizational Dynamics, Vol. 21, No. 3, pp.59-71.

Weber, M. (1930) The Protestant Ethic and the Spirit of Capitalism, Routledge, New York, NY.

Zaudtke, D. and Ammerman, D. (1997) 'Family business: the next generation', Management Review, February, Vol. 86, No. 2, pp.55-57. 